\title{
Preface to the Revised Edition
}

The introduction written for this book by Sumner Welles, I have let stand. His services to the public, and his services in connection with the editorship of this series, are known to every student of American foreign relations. They need no further acknowledgment.

As I view my preface to the first edition, I am aware of how much the atmosphere has changed since 1947 . Written as it was when the "good-neighbor" policy was at its height and amid the euphoria generated by victory in war and by the creation of the United Nations, it seems to me today somewhat outdated. We ought still to desire good relations with Latin America. But the difficulties in the way of maintaining such relations seem far greater than they did nineteen years ago. The immense economic difference between this enormously rich country and its "southern neighbors," as Monroe called them, the ideological threat of Communism, and the involvement of the United States in Europe and Asia have given a new color to our relations with the peoples of the Caribbean. The picture is by no means all gloomy; indeed the reader will find much that is cheerful in the pages that follow. But the problems are not the same. I have sought to analyze them in a dispassionate but not unsympathetic spirit.

The last two chapters of the first edition I find less relevant today than they were in 1947. The United Nations will probably not have much to do with our relations with the states herein studied. While much of what I wrote on the psychological background of our relations remains true, the generalizations I then 
viii Preface to the Revised Edition

set down have been sufficiently assimilated by students of Latin American affairs to justify their omission.

The personal acknowledgments, which I set down at the end of my earlier preface, to Richard C. Wade, now a professor at the University of Chicago, for his cheerful and helpful labors, to Douglas Parks, who has been most helpful in bringing my book up to date, and to Marjorie Christopher (née Gilles), my longtime friend and former secretary, deserve repetition.

Rochester, New York

Dexter Perkins

February 1966 